\title{
The Distribution of Jelly-fish
}

Accounts of material collected by the Carlsberg Foundation's Oceanographical Expedition round the world in 1928-30, and the earlier "Dana" expeditions under the leadership of the late Professor Johannes Schmidt are still being published. The latest report is by P. L. Kramp of the Zoological Museum, Copenhagen, on "The Hydromedusae of the Pacific and Indian Oceans", sections 2 and 3 (Dana Report, No. $72 ; 1968)$. This report is a sequel to the first section issued in 1963 (Dana Report, No. 63). A companion volume by the same author on the Hydromedusae of the Atlantic Ocean collected by the same expedition appeared in 1959 (Dana Report, No. 46).

The latest report consists of descriptions, figures and keys for the identification of all the Hydromedusae from the Indian and Pacific Oceans, a detailed discussion of their zoogeography and a comparison with the Hydromedusae collected from the Atlantic. As before, Kramp attempts to explain the distribution of these jelly-fish. They are divided into three ecological groups; neritic species, slope species and oceanic species. The oceanic species are further divided into those which are epipelagic (belonging to the upper water layers down to about 150-250 metres below the surface) and the bathypelagic forms in intermediate and deep water layers below the epipelagic zone. There are also a few oceanic species which are eurybathic, that is, they are found at all depths in the oceans.

The neritic region is the pelagic region above the continental shelves usually at depths within about 200 metres. The Hydromedusae in this region are mainly meropelagic Leptolina which are usually freed from hydroids attached to objects on the bottom within the shelf region. Kramp has found that the distribution of neritic Hydromedusae follows in general Ekman's division of the shelf fauna into zoogeographical regions and sub-regions (Zoogeography of the Sea, 1953), although the limits are less sharp for these pelagic animals. There are in fact characteristic differences in the composition of Hydromedusae in the different regions, but some interchange of species between the regions takes place naturally.

There are a number of species which are neither neritic or oceanic. They occur mainly in the deeper water layers but are presumably meropelagic as they are derived from hydroids attached to the bottom of the continental slopes outside the neritic areas. These "slope species" do not constitute a sharply defined ecological group because many of them may be found in the upper layers particularly near the coasts, where upwelling of water from the deeper layers occurs. Their geographical distribution, however, cannot be explained by the movements of the currents in the upper layers. Eleven species of Anthomedusae and Leptomedusae and one Trachymedusa are included in this category.
Oceanic species are carried along with currents, and they may also be caught by descending or upwelling water masses. The majority of oceanic species are the holopelagic Trachymedusae and Narcomedusae which are not directly dependent on the coastal shelves. There are also, however, a few meropelagic Anthomedusae and Leptomedusae which for various reasons may spread widely over the oceans. The epipelagic sipecies are partly exposed to the same currents as the neritic species, but the zoogeographical regions are more simplified; they can be divided into arctic, northtemperate, warm-water, south-temperate and antarctic. The oceanic bathypelagic fauna consists of forty species, one of which is endemic in the Mediterranean. With the exception of the arctic basins (with three endemic species) there is free communication between the deep water in the oceans; the ridges between the deep basins do not form a barrier to the medusae as they drift with the slowly moving currents in the deep water.

Professor Kramp writes at some length on the interchange of faunas between the Atlantic and the Indian and Pacific Oceans. An explanation for the distribution of noritic Hydromedusae is more difficult than for the oceanic faunas. Kramp is able, however, to reach some conclusions: (1) no species of recent Hydromedusae has been dispersed from one ocean to another through the Tertiary Tethys Sea; (2) the populations of IndoPacific and Atlantic neritic Hydromedusae in the warm. water regions have developed independently since the end of the Tertiary; in the Quaternary a limited interchange of species has taken place around South Africa in both directions; (3) there has been an interchange of oceanic epipelagic species mainly south of Africa, and many have a circumglobal distribution. Some species have originated in separate Pacific, Malayan or Atlantic areas and have given rise to local populations without being dispersed to other oceans; (4) the bathypelagic fauna of Hydromedusae is entirely of Atlantic origin.

\section{Molecular Biology of Viruses}

\section{from our Cell Biology Correspondent}

Trie symposium on "The Molecular Biology of Viruses" which the Society of General Microbiology held at Imperial College, London, on April 2 and 3 was quite an ambitious affair. The idea was to discuss what is known, at the molecular level, about the functioning of viruses-the whole gamut of plant, animal and bacterial viruses. The society hoped that by bringing under one roof specialists working on all three classes of viruses, there would be a cross-fertilization of ideas. The organizers recognized that the molecular biology of bacteriophages is far better understood than that of the more complex animal and plant viruses, but they 